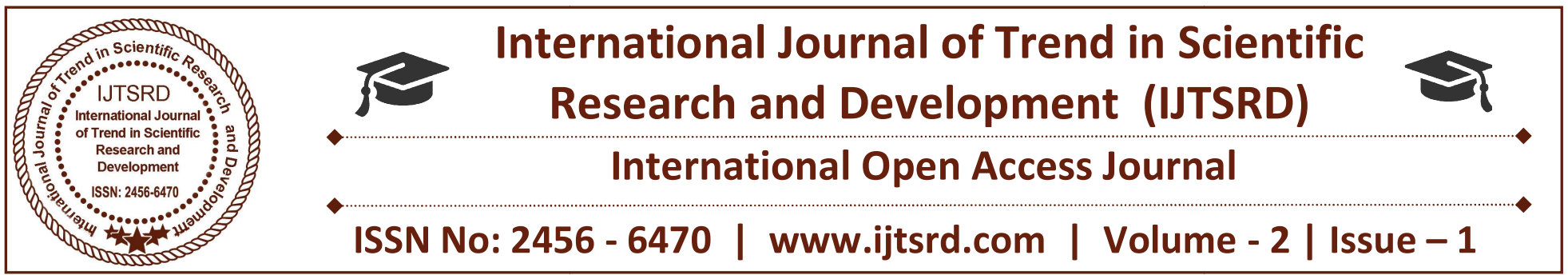

\title{
Kanthapura as a Postcolonial Text: Treatment of Indian Sensibility in Kanthapura
}

\author{
Ishfaq Hussain Bhat \\ Department of English,University of Kashmir, \\ Thune, Kangan, Ganderbal, Jammu and Kashmir
}

\section{ABSTRACT}

Raja Rao is beyond doubt one of the most prominent Indian novelists writing in English. He has laid a strong foundation to Indian English Novel together with Mulk Raj Anand and R. K. Narayan. Raja Rao, in particular, has been very instrumental in the development of Indian English Novel. His novels are replete with Indian sensibility characterized by his unique style and subject matter. His first and bestknown novel Kanthapura is a remarkable expression of the Indian sensibility. The novel is Indian both in theme and treatment. Acceptance of an Indian way of writing in English and Indianization of the novel as a form of literature is what makes Raja Rao postcolonial in style. The paper attempts a postcolonial reading of Kanthapura focusing on Raja Rao's style characterized by Indian sensibility and Indianness.

Keywords: Postcolonial, Indianness, Indian sensibility, language, myth

"Postcolonial as we define it does not mean post-independence or 'after colonialism' for this would be to falsely ascribe an end to the colonial process. Post-colonialism, rather, begins from the very first moment of the colonial contact. It is the discourse of oppositionality which colonization brings into being." (Ashcroft, Griffiths, Tiffin, 117)

As a postcolonial text Kanthapura focuses on the encounter of the two cultures and shows how while countering the imposing culture the weaker one redefines and reinterprets its tradition while it seeks its identity. Raja Rao deconstructs the myth of the power of the foreign ruler, views resistance as an enabling strategy and examines in detail the meaning and practice of ahimsa and satyagrahas.

Raja Rao's Indianization of the novel form and emphasis on the decolonization of English langusge can be interpreted from the postcolonial perspective. Raja Rao did not consider English language to be an alien language but he claims it to be the language of "our intellectual make-up --- like Sanskrit and Persian was before--- but not of our emotional make-up...We cannot write like the English. We should not. We cannot write only as Indians. We have grown to look at the large world as part of us. Our method of expression therefore has to be a dialect which someday proves to be as distinctive and colourful as the Irish or the American. Time alone will justify it." (Rao, v)

Once asked about this distinctiveness of Indian language in an interview with P. Bayapa Reddy, Raja Rao answered: "I certainly feel that Indian English has acquired such distinction. When I read some of the journals of India, I feel that they have overcome their Victorian English. They write good English." (Reddy, 272) In the same interview he claimed: "I have written puranas but not novels." (Reddy, 274) This statement expresses Raja Rao's style of writing novels characterized by Indian sensibility.

By deviating from the conventional and British ways of writing novels, Raja Rao produced literature in an alien language yet native in style. In Kanthapura, Raja Rao has experimented with the English language to evolve a suitable medium to 
express Indian sensibility. Raja Rao uses three techniques to infuse his novel with Indianness: literal translation of Indian idioms, phrases, proverb, etc; change in the syntax; and Indian imagery. Meenakshi Mukherji while acknowledging his merit states: "The evolving of an Indian-English which is adequate enough to express Indian, even regional flavor, without ceasing to be English, is Raja Rao's most significant contribution." (Tilak, 131)

The language of Kanthapura is replete with Indian idiom, Indian imagery and rural colour.

Raja Rao has used many Indian phrases and proverbs in the novel to give it a quintessential Indian flavor:

"Every squirrel has his day." (Rao, 77)

"The policemen are not your uncle's sons." (Rao, 162)

"If you are the sons of your father." (Rao, 52)

"We are the lickers of your feet." (Rao, 52)

"You cannot straighten a dog's tail." (Rao, 140)

"With his week's earning at his waists." (Rao, 140)

The influence of his mother-tongue can also be seen in Kanthapura. His description of the village is quintessentially Kannad: "High on the Ghats is it, high up the steep mountains that face the cool Arabian seas, up the Malabar coast is it." (Rao, 1) "Defend one must against evil."

$\left(\right.$ Rao, 86) ${ }^{3}$

Raja Rao's decolonization of English language gets an artistic manifestation in his use of Indian flavoured abuses in the novel. Venkama abuses her sister-in-law in a typical Indian style:

"If her parents are poor, let them set fire to their dhoti and sari and die. Oh, if only I could have had the courage to put lizard-poison into their food." (Rao, 10)

Typical Indian abuses have also been used in the following statements:

"Then there is such a battle of oaths - 'son of concubine' - 'son of a widow' "' (Rao, 59)
"I'll sleep with your wife," "You donkey's husband." (Rao, 59)

"Oh, you prostitute of a wind," "She is showing her tricks again," "Stop, you bitch." (Rao, 17)

However, Raja Rao in the Foreword says that it is not easy to use English language to depict Indian sensibility:

"The telling has not been easy. One has to convey in a language that is not one's own the spirit that is one's own. One has to convey the various shades and omissions of a certain thought-movement that looks maltreated in an alien language. I use the word 'alien' yet English is not really an alien language to us. It is a language of our intellectual make-up like - Sanskrit and Persian was before - but not of our emotional make-up. We are instinctively bilingual, many of us writing in our own language and in English. We cannot write like the English. We should not." ( Rao, v)

Raja Rao deviates in his approach to his subject-matter from the western novelists so much that David McCutchion, in his critique of the novel asks: "Is this a novel at all?...All the central concerns of the western novel are absent - social relations, psychological motivation, characterization, judgement, a passion for character." (Tilak, 116) The answer to his question is in Raja Rao's Foreword to Kanthapura: "We have neither punctuation nor the treacherous 'ats' and 'ons' to bother us - we tell one interminable tale. Episode follows episode and when our thoughts stop our breath stops, and we move on to another thought." (Foreword, v)

The method of narration used by Raja Rao in Kanthapura is typically Indian. The story is told by an old woman Achakka who narrates the story for the benefit of a new comer, years later.

Achakka's unlettered imagination provides Raja Rao the perfect opportunity to mingle God with men and to infuse his narrative with other-worldliness. Raja Rao's use of myth in the novel also adds to the Indianness of the novel. In Kanthapura he shows a remarkable parallelism between Ramayana and the freedom struggle of India. He represents swaraj as Sita, Mahatama as Rama and Nehru as Bharatha. He 
compares Rama's journey to Lanka to bring Sita to Gandhi's trip to England to participate in the Second Round Table Conference: "They say the Mahatama will go to the Red-Man's country and he will get us Swaraj. He will bring us Swaraj, the Mahatama. And we shall be all happy. And Rama will come back from exile and Sita will be with him, for Ravana will be slain and Sita freed, he will comeback with Sita on his right in the chariot of the air and brother Bharatha will go to meet them with the worshipped sandal of the master on his head. And as they enter Ayodhya, there will be a rain of flowers." (Rao, 183)

Raja Rao's use of language is dramatic and truly creative. Narasimhaiah states: "The emotional upheaval that overtook Kanthapura could only find expression by breaking the formal English syntax to suit the sudden changes of mood and sharp contrasts in tone...It had to be a highly original style, a technical innovation indistinguishable from an essential Indian sensibility.” (Tilak, 133)

To wrap up the discussion, many things need to be brought together. Raja Rao uses the language of the colonizer to portray Indian sensibility. He calls for the decolonization of English language and he does not consider it to be an alien language. His way of writing in English language is different from the colonizers. His use of 'Language becomes a medium for expressing the complexity and uniqueness of Indian lifestyle. ${ }^{4}$ Thus Raja Rao through Indianisation of the novel form and the English language succeeds in redefining and reinterpreting history and tradition. His way of writing novel in a typical Indian style: using literal translations of Indian phrases, idioms, juxtaposition of Indian freedom struggle with Ramayan, his Puranic art of narration, his Indianness makes Kanthapura a postcolonial text. It would not be wrong to conclude the discussion on Raja Rao's style and his portrayal of Indian sensibility in the novel with a quotation from V. K. Kantak: "The language has shaken off all traces of foreign acquisition and begun to assert its inalienable rights as an independent idiom.The word has become the perception."

(Tilak, 135)

\section{REFERENCES}

[1] Ashcroft, B; g. Griffiths and Helen Tiffin, eds. The Post Colonial Studies Reader. London:Routledge, 1995. Print.

[2] Reddy, P. Bapaya. Aspects of Contemporary World Literature. Atlantic Publishers and Distributors. 2008. Print.

[3] Dayal, P. Raja Rao, A study of His Novels. Atlantic Publishers and Distributors, New Delhi. 1991.

[4] Rao, Raja. Kanthapura. Oxford University Press: New Delhi 1963. Print.

[5] Kantak, V.Y. "The language of Indian Fiction in English." In Critical Essays on Indian Writing in English, edited by M.K.Naik and el al, Dharwad: The Karnataka University Press, 1968.

[6] Tilak, Dr. Raghukul. Raja Rao Kanthapura [ A Critical Study ]. Rama Brothers.2011.

\section{Web Sources:}

[1] Chapter II Raja Rao's Kanthapura and Kamala Markandaya's ...- Shodhganga PDF Shodhganga.inflibnet.ac.in $>06$-chapter2, p, 38 .

[2] Chapter II Raja Rao's Kanthapura and Kamala Markandaya's ...- Shodhganga PDF Shodhganga.inflibnet.ac.in $>06$-chapter2, p. 38.

[3] www.researchscholar.co.in

[4] Chapter II Raja Rao's Kanthapura and Kamala Markandaya's ...- Shodhganga PDF Shodhganga.inflibnet.ac.in $>06$-chapter2, p. 51 . 